
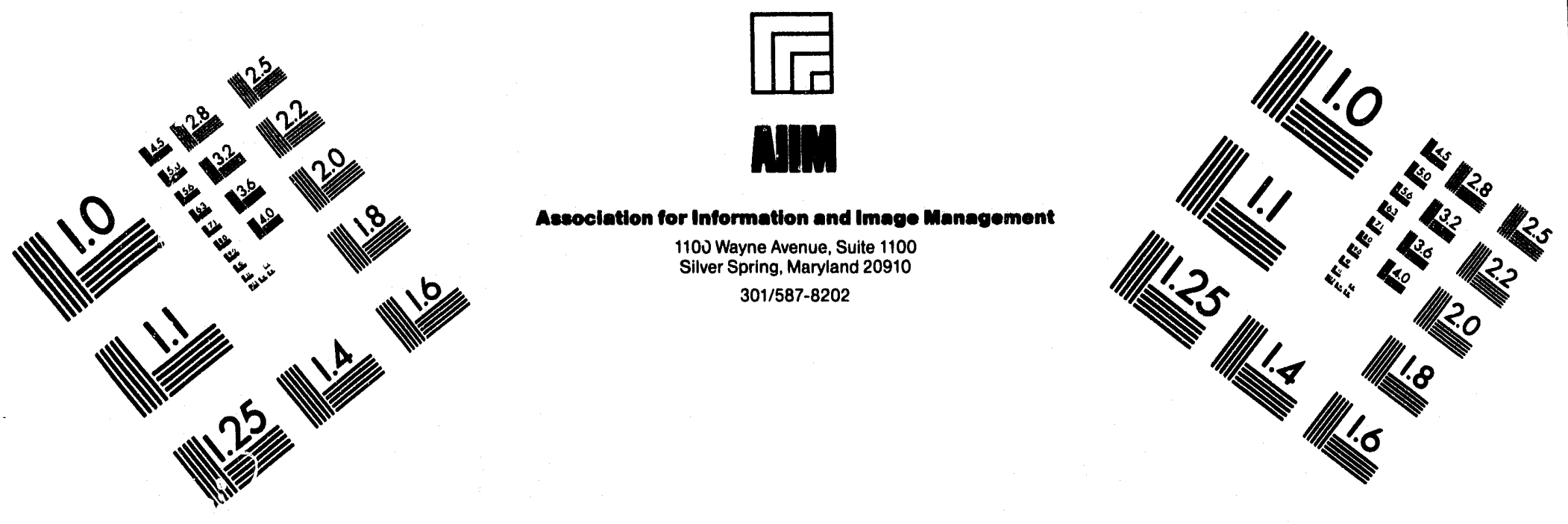

Centiliner

$\begin{array}{llllllllllllllll}1 & 2 & 3 & 4 & 5 & 6 & 7 & 8 & 9 & 10 & 11 & 12 & 13 & 14 & 15 & \mathrm{~mm}\end{array}$

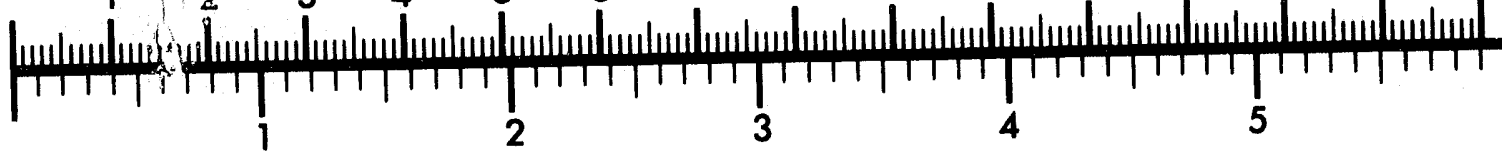
Inches
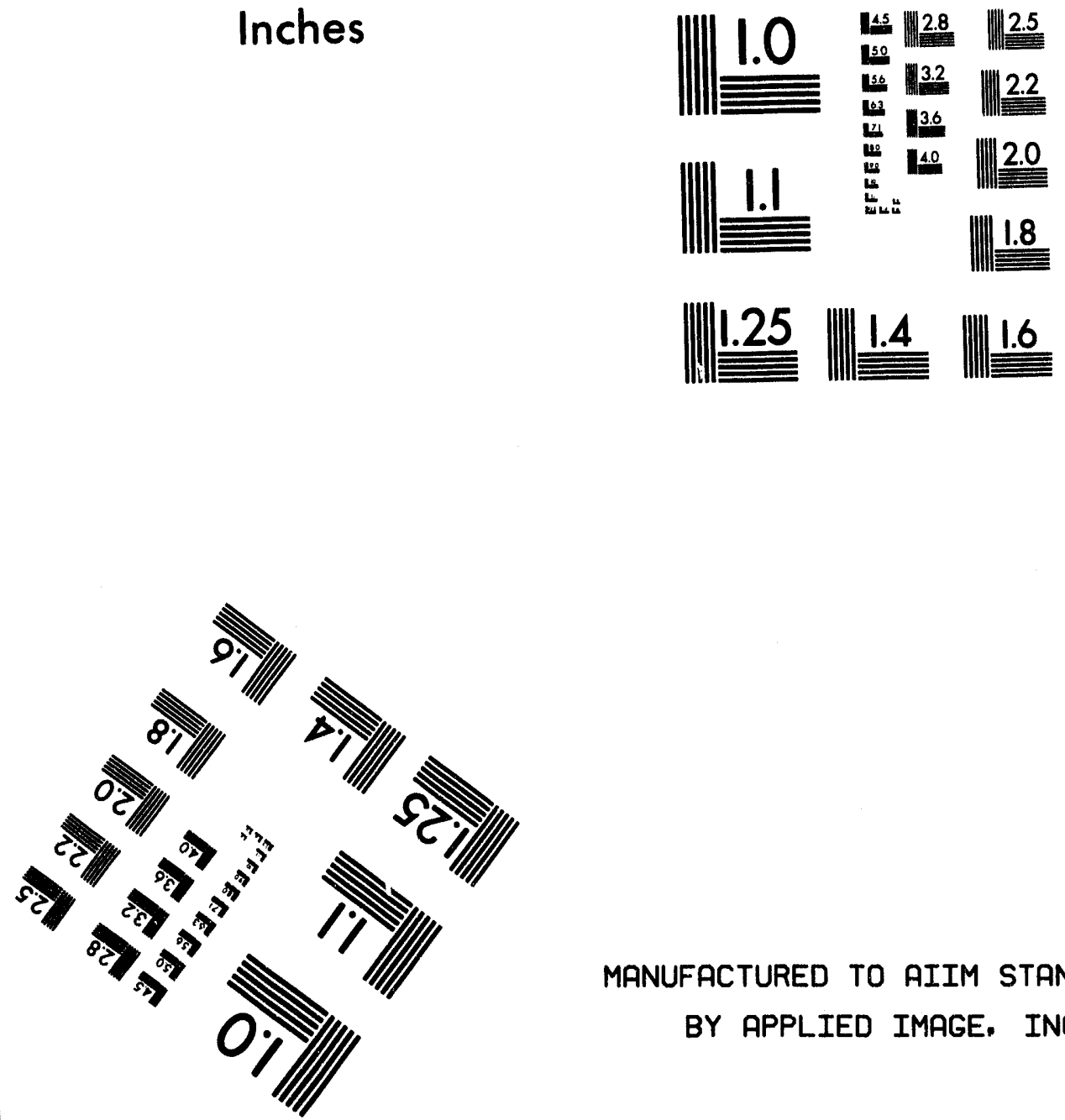

MANUFACTURED TO AIIM STANDARDS

BY APPLIED IMAGE, INC.

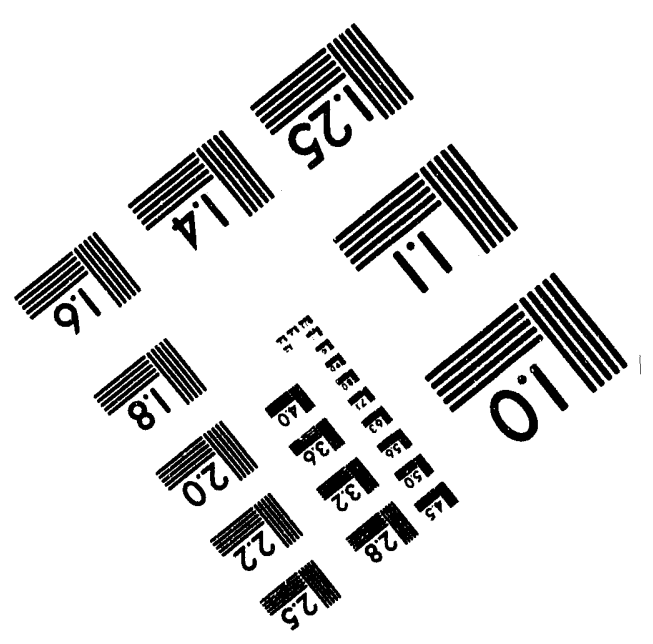



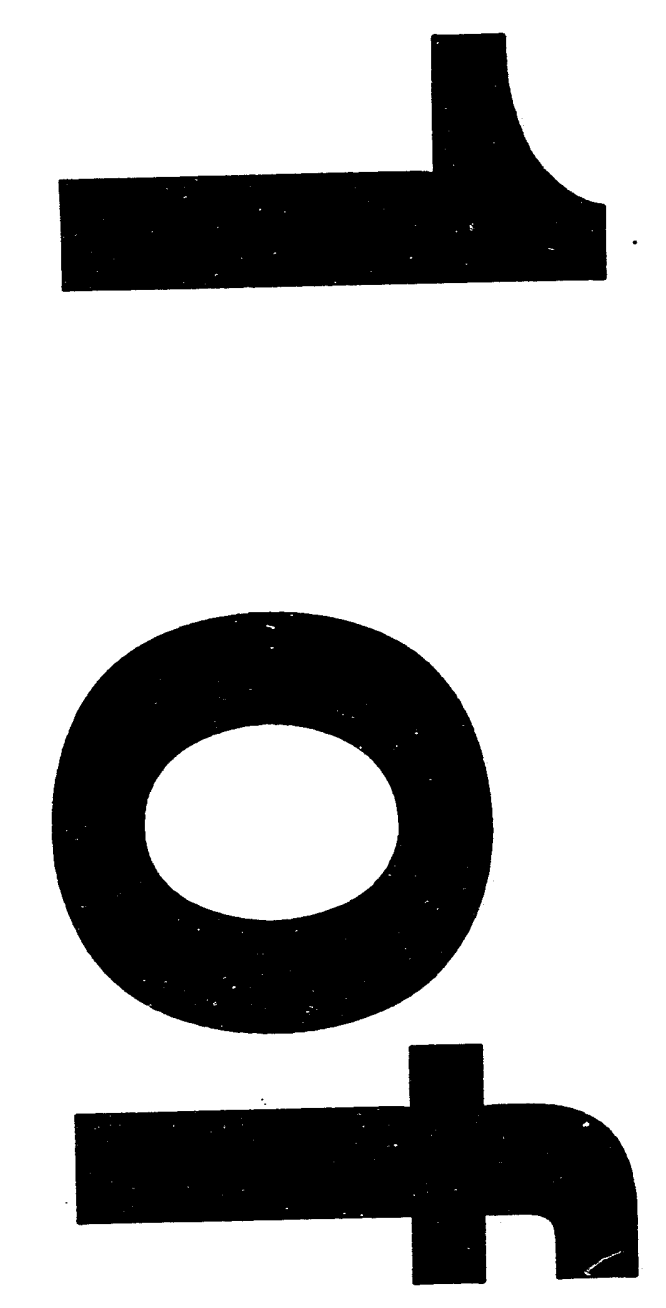

i

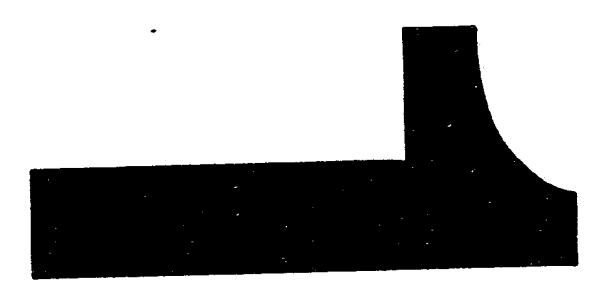




\title{
CAPTURE OF GREEN-HOUSE CARBON DIOXIDE IN PORTLAND CEMENT
}

\author{
ARUN S. WAGH, , DILEEP SINGH, JOSE PULLOCKARAN, \\ ANDLERRY KNOX \\ Energy Technology Division \\ Argonne National Laboratory \\ 9700 S. Cass Avenue, Argonne, II 60439
}

\section{DISCLAIMER}

\begin{abstract}
This report was prepared as an account of work sponsored by an agency of the United States This report was prepared as an account of work sponsored by an agency of the United sther Government. Neither the United States Government nor any agency thereof, nility or responsiemployees, makes any warranty, express or implied, or assumes any legal liability or respons bility for the accuracy, completeness, or usefulness of any information, apparatus, product, Referprocess disclosed, or represents that its use would not infringe privately owned rights. Refor, ence herein to any specific commercial product, process, or service by trado name, trademark, manufacturer, or otherwise does not necessarily constitute or imply its endorsemon, The views mendation, or favoring by the United States Government or any agency thereor. The vi the and opinions of authors expreseded herein do not

United States Government or any agency thereof.
\end{abstract}

Final Report to METC on Carbonation of Cement Project.

Work supported by U.S. Department of Energy, Assistant Secretary for

Fossil Energy, under contract W-31-109-Eng-38. 


\begin{abstract}
A novel process has been developed to sequester green-house carbon dioxide produced by the cement industry in precast cement products. Typically, $10-24$ wt. \% of $\mathrm{CO}_{2}$ produced by calcination of calcium carbonate during clinkering of the cement may be captured. The carbonation process also cures the cement paste within minutes into hard bodies. The process maintains high $\mathrm{pH}$ conditions during curing to allow conventional steel reinforcement of concrete. The process will save time and money to the cement industry, and at the same time, help them to comply with the Clean Air Act by sequestering the green-house carbon dioxide.
\end{abstract}


CONTENTS

\section{INTRODUCTION}

II. STUDIES IN CEMENT PASTE CURED IN CO 2 ENVIRONMENT

II.1 Characterization of Portland cement and the $\mathrm{CO}_{2}$ budget

II.2 Method of estimation of $\mathrm{CO}_{2}$ capture

III. IN SITU CARBONATION'OF PORTLAND CEMENT USING AMMONIUM CARBONATE AS A VEHICLE OF $\mathrm{CO}_{2}$

III.1 Ammonium carbonate as a vehicle of $\mathrm{CO}_{2}$

III.2 Characterization of Portland cement and the $\mathrm{CO}_{2}$ budget

III.3. Estimation of $\mathrm{CO}_{2}$ captured

III.4 Carbonation in concrete

III.5 Effect of carbonation on reinforcement with steel

III.6 Microstructure of the carbonated cement

IV. DISCUSSION

REFERENCES 


\section{LIST OF FIGURES}

Figure

Caption

Page no.

1 World $\mathrm{CO} 2$ production due to

cement manufacturing.

2: X-ray diffraction output of

Portland cement Type I.

3: Differential thermal analysis of

cement cured in $\mathrm{CO} 2$.

4: X-ray diffraction output of cement cured in $\mathrm{CO} 2$.

5: Temperature rise during

carbonation setting of cement.

6: Time dependence of carbonation in concrete.

7: $\mathrm{CO} 2$ capture as a function of wt. \% of cement in concrete.

8: Proposed $\mathrm{CO} 2$ cycle in the cement industry. 


\section{LIST OF TABLES}

Table no.

Title

Page no.

1 : Composition of Portland cement Type I.

2: $\quad \mathrm{CO} 2$ budget in Portland cement.

1

3: Phase evolution in carbonated cement

at high temperatures.

4: Strength and porosity data of carbonated supplies.

5: Weight loss due to decomposition of various components in the carbonated concrete. 


\section{INTRODUCTION}

Increasing levels of "greenhouse" gases has raised serious concern regarding possibilities of global climatic change. Carbon dioxide $\left(\mathrm{CO}_{2}\right)$ is the single largest greenhouse gas, which accounts for $55 \%$ of the total volume of greenhouse gases produced annually. Utility industries followed by cement industries are responsible for this production. This project dealt with sequestering $\mathrm{CO}_{2}$ released during production of cement in products made of cement itself, so that the entire industry can be partially self-sufficient in reducing its emissions of $\mathrm{CO}_{2}$.

I.1. Contribution of Green House $\mathrm{CO}_{2}$ by the Cement Industry:

Cement industry contributes $\mathrm{CO}_{2}$ to greenhouse gases in two different ways. Approximately $64 \%$ of the cement is calcium oxide, which is obtained by calcining calcium carbonate $\left(\mathrm{CaCO}_{3}\right)$ in the form of lime stone. This calcining follows the reaction,

$$
\mathrm{CaCO}_{3}-\cdots-\cdots \mathrm{CaO}+\mathrm{CO}_{2} \text {. }
$$

Calcium, oxide becomes a component of the cement and $\mathrm{CO}_{2}$ is released to the atmosphere. The other source of $\mathrm{CO}_{2}$ during production of cement is due to the use of fuel for power production needed for calcining and clinkering. It is estimated that these two sources emit nearly equal amount of $\mathrm{CO}_{2}$. For each ton of cement produced, approximately 0.5 ton of $\mathrm{CO}_{2}$ is produced by each of these two sources and hence the total $\mathrm{CO}_{2}$ production is 1 ton [Source: Portland Cement Association]. 


\section{WORLD CO2 PRODUCTION DUE TO CEMENT MANUFACTURING}

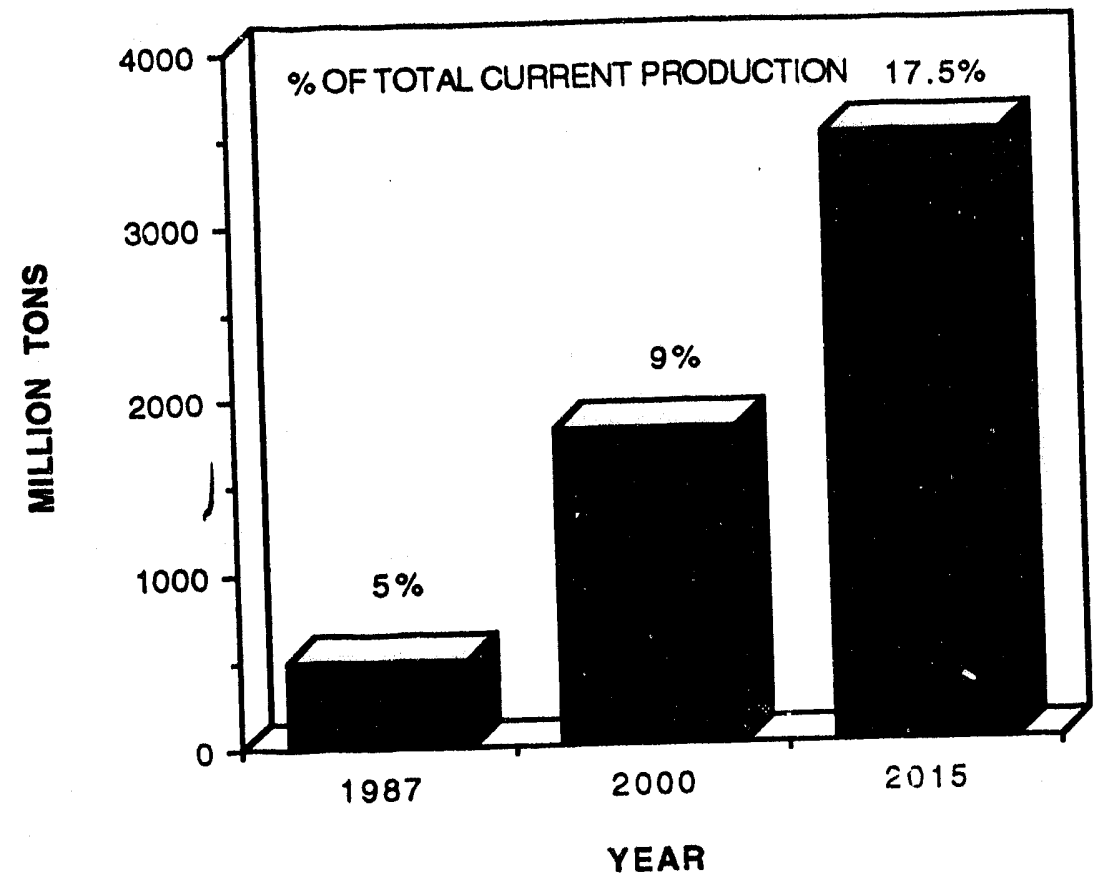

FIGURE 1: World carbon dioxide production due to cement manufacturing [1].

Fig. 1 shows the projection of world $\mathrm{CO}_{2}$ production by the cement industry. Though cement industry contributed only $5 \%$ of the total $\mathrm{CO}_{2}$ produced, its share will keep increasing because of the population rise and hence the increase of activities in the construction sector where cement is the major ingredient. In particular, the rapid population growth in China and India will require increase of cement production, and as a result, the cement production will also rise. This rise is responsible for the projected increased share of $\mathrm{CO}_{2}$ production by the cement industry [1] as shown in Fig. 1. It is estimated that by the year 2015, 3500 million tons of $\mathrm{CO}_{2}$ will be produced annually, which is 3.5 times that of the current cement 
production rate. This lion's share of $\mathrm{CO}_{2}$ production by the cement industry clearly indicates that sequestering this $\mathrm{CO}_{2}$ may help reduce the greenhouse gases significantly.

In the United States, reduction of $\mathrm{CO}_{2}$ emissions may have regulatory importance also. The Clean Air Act of 1990 will require that the emissions of greenhouse gases be reduced by the turn of the century to their 1990 levels. To comply with this act, every industry may require new technologies to reduce emissions. The method investigated here may provide a novel process to reduce $\mathrm{CO}_{2}$ emissions in the cement industry and thereby comply with the Clean Air Act. 


\section{Carbonation of cement as a method of sequestering greenhouse $\mathrm{CO} 2$}

It is well known that certain lime based products harden by aging due to carbonation. Greek and Roman lime mortars made of $\mathrm{Ca}(\mathrm{OH})_{2}$ have been shown to slowly form $\mathrm{CaCO}_{3}$ and strengthen by carbonation when exposed to atmospheric $\mathrm{CO}_{2}$. Berger et al. [2], Young et al. [3] and Goodbrake et al. $[4,5]$ extended these studies to investigate the effect of $\mathrm{CO}_{2}$ and water on cement. These authors worked with laboratory synthesized calcium trisilicate, $3 \mathrm{CaO} \cdot \mathrm{SiO}_{2}\left(\mathrm{C}_{3} \mathrm{~S}\right)^{*}$ and calcium disilicates, $2 \mathrm{CaO} . \mathrm{SiO}_{2}\left(\mathrm{C}_{2} \mathrm{~S}\right)^{*}$, which are the major binding phases of the cement. They showed that, if these binders are cured in the presence of humid $\mathrm{CO}_{2}$ environment, they rapidly develop strength and sequester large amount of $\mathrm{CO}_{2}$.

Berger et al. [2] and Young et al. [3] suggested that the sequestration of $\mathrm{CO}_{2}$ in Porland cement is a result of the chemical reactions given in Eq. (1-4) given below. These reactions are written in cement chemistry notations, i.e., $\mathbf{H}=\mathrm{H}_{2} \mathrm{O}, \mathrm{C}=\mathrm{CaO}, \boldsymbol{C}=\mathrm{CO}_{2}, \mathrm{~S}=\mathrm{SiO}_{2}, \mathrm{C}_{\mathbf{n}} \mathrm{S}=\boldsymbol{\beta}$-dicalcium silicate $\left(C_{2} S\right)$ for $n=2$, and tricalcium silicate $\left(C_{3} S\right)$ for $n=3$.

$$
\begin{aligned}
& C+\mathrm{H}<-\cdots-->\mathrm{H} C \\
& \mathrm{C}_{\mathrm{n}} \mathrm{S}+(\mathrm{n}-\mathrm{x}) \mathrm{H} C+\mathrm{w} H-\cdots \mathrm{C}_{\mathrm{x}} \mathrm{S} \mathrm{H}_{\mathrm{y}}+(\mathrm{n}-\mathrm{x}) \mathrm{CC}
\end{aligned}
$$

where, $w=y-n+x$,

$$
C_{\mathrm{x}} \mathrm{S} \mathrm{H}_{\mathrm{y}}+\mathrm{C} \cdots-\cdots \mathrm{C}_{x} \mathrm{SH}_{y}
$$

where $\mathrm{x}>x$ and $\mathrm{y}>y$.

\footnotetext{
* Cement chemistry notation
} 
These equations suggest that the two main cement phases, i. e. the dicalcium silicate and the tricalcium silicate are responsible for sequestration of $\mathrm{CO}_{2}$ by forming calcium carbonate in the process. They, further suggest that progressive carbonation of the C-S-H would lead eventually to silica gel $(x=0)$. Eq. 2 now becomes

$$
\mathrm{C}_{\mathrm{n}} \mathrm{S}+\mathrm{nHC}+\mathrm{zH}--\cdots>\mathrm{SH}_{\mathrm{z}}+\mathrm{n} \mathrm{CC}
$$

where $\mathbf{S} \mathbf{H}_{\mathbf{Z}}$ is the silica gel. These reactions were investigated by Goodbrake et al. [3] in laboratory synthesized $\mathbf{C}_{2} \mathbf{S}$ and $\mathbf{C}_{3} \mathrm{~S}$. We exploited this mechanism to sequester $\mathrm{CO}_{2}$ in commërcial Portland cement for rapid setting.

\section{II.1. Characterization of Portland cement and the $\mathrm{CO}_{2}$ Budget}

Six types of Portland cements are commercially sold. They are called Type I-V and the last one is called While cement. Their composition, particle size and formation methods are vary in each type. We used Commercial Portland cement (CAS \# 65997 - 15 - 1), which was Type I cement in this study. Type I cement is used mostly in building industry. This cement was characterized in the laboratory, before its use.

Table 1 gives the chemical composition of the Portland cement Type I. As one can see, the content of $\mathbf{C}_{2} \mathbf{S}$ and $\mathbf{C}_{3} \mathrm{~S}$ in this cement is high and should be responsible for the sequestration of $\mathrm{CO}_{2}$ in a significant amount.

The mineral phases of the cement powder are shown in the XRD output in Fig. 2.

TABLE 1: Composition of Portland cement Type I. [5] 


\begin{tabular}{lllll}
\hline \hline \multicolumn{2}{l}{ Chemical composition of cement } & \multicolumn{3}{c}{ Potential compound composition } \\
\hline Oxide & $(\%)$ & Chemical phase & $(\%)$ & \\
\hline $\mathrm{SiO}_{2}$ & 20.9 & $\mathrm{C}_{3} \mathrm{~S}$ & 55 & $\cdots$ \\
$\mathrm{Al}_{2} \mathrm{O}_{3}$ & 5.2 & $\mathrm{C}_{2} \mathrm{~S}$ & 19 \\
$\mathrm{Fe}_{2} \mathrm{O}_{3}$ & 2.3 & $\mathbf{C} \mathbf{A}$ & 10 \\
$\mathrm{CaO}$ & 64.4 & $\mathbf{C}$ & $\mathbf{A F}$ & 7 \\
$\mathrm{SO}_{3}$ & 2.9 & Other & 9 \\
\hline
\end{tabular}

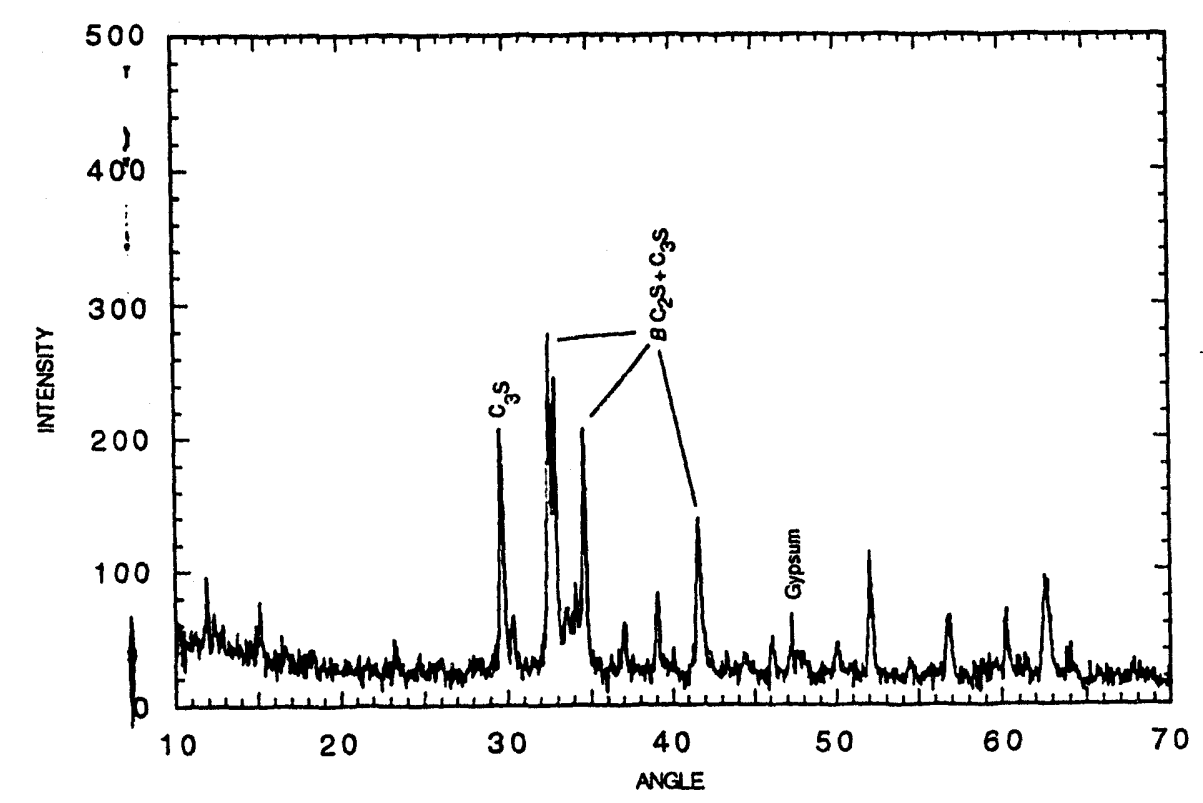

$\mathrm{T}$

FIGURE 2. X-ray diffraction output of Portland cement Type I.

In Fig. $2, \mathrm{C}_{3} \mathrm{~S}$ and $\beta \quad-\mathrm{C}_{2} \mathrm{~S}$ phases are dominant. There is no evidence of any $\mathrm{CaCO}_{3}$, but one can see a peak of gypsum, which might have been due to the $\mathrm{SO}_{3}$ content in the powder. As we shall see later, this gypsum 
forms an entirely new room temperature setting cement called ettringite.

Though this is a minor phase, it has been noted in the literature [6] that this phase is affected by carbonation. Thus the net effect of carbonation is due to carbonation of $\mathrm{C}_{3} S$ and $\beta \quad-C_{2} S$ phases and also that of the ettringite phase. However, the minor phase of ettringite will not affect the overall budget of the $\mathrm{CO}_{2}$ intake, though it may affect the strength characteristics of the carbonated cement slightly. In this initial study, we will ignore this phase in calcul ting the $\mathrm{CO}_{2}$ budget in Portland cement.

TABLE 2. $\mathrm{CO}_{2}$ budget in Portland cement

\begin{tabular}{|c|c|c|c|c|}
\hline $\begin{array}{l}\text { Cement } \\
\text { type }\end{array}$ & 1 & $\begin{array}{l}\mathrm{CaO} \text { content } \\
\text { (wt.\%) }\end{array}$ & $\begin{array}{l}\mathrm{CO}_{2} \text { release due } \\
\text { to calcination of } \\
\mathrm{CaCO}_{3}(w \mathrm{t} . \%)\end{array}$ & $\begin{array}{l}\text { Theoretical intake } \\
\text { (wt.\%) }\end{array}$ \\
\hline$I$ & $i$ & 64.4 & 50.6 & 41.5 \\
\hline II & ! & 63.6 & 49.97 & 41.76 \\
\hline III & ! & 64.9 & 50.99 & 42.07 \\
\hline IV & : & 62.3 & 48.95 & 41.23 \\
\hline V & & 64.4 & 50.6 & 44 \\
\hline White & & 65 & 51.07 & 42.6 \\
\hline
\end{tabular}


Table 2 ives the $\mathrm{CO}_{2}$ budget in various types of the Portland cement, estimated on the basis of the reactions given by Equations 1-4. Based on the numbers in this Table, one may conclude that, overall the . total $\mathrm{CO}_{2}$ release during manufacture of the cements and the theoretical upper limits for sequestration are nearly the same for all the cement types. Further, the theoretical intake ranges between $92-95 \%$ of the release of $\mathrm{CO}_{2}$ due to calcination of calcium carbonate. This implies that, independent of which type of cement is in use, fequestration of $\mathrm{CO}_{2}$ in Portland cement may be equally effective for curtailment of green-house $\mathrm{CO} 2$.

II.2 Method pf estimation of $\mathrm{CO}_{2}$ captured :

If sequestration of $\mathrm{CO}_{2}$ results in the formation of $\mathrm{CaCO}_{3}$, then it should be possiple to decompose $\mathrm{CaCO}_{3}$ at $\sim 900{ }^{\circ} \mathrm{C}$ into $\mathrm{CaO}$ and $\mathrm{CO}_{2}[6]$ and estimate the amount of $\mathrm{CO}_{2}$ that has escaped from the material. Berger at al [2] calcined the trisilicate and disilicate samples at $980^{\circ} \mathrm{C}$ to estimate the intake of $\mathrm{C}_{92}$. The commercial cement used in our study contains, in addition to the disilicate and trisilicates, other components such as calcium aluminate, and herefore it is necessary to ensure that any other high temperature reactions do not interfere with this estimate. To investigate this, differential thermal analysis (DTA) of the sample was done.

DTA studies involve monitoring the weight of the sample as it is heated from the room temperature to a desired higher temperature. The rate of loss in weight due to evolution of gases such as $\mathrm{CO}_{2}$ is detected by 
dips in the endotherms plotted as a function of the temperature. From this study, one can identify exact temperatures at which such evolutions occur.

The DTA output of the carbonated cement samples is shown in Fig. 3. As one may notice there are four dips at elevated temperatures. These are given in Table 3 along with the transformations occurring in the material at these temperatures. These transformations suggest that to estimate the content of $\mathrm{CO}_{2}$ in the cement, we can fire the specimens at temperatures $>825 \infty \mathrm{C}$ and find the weight loss occurring between $540^{\circ} \mathrm{C}$ and that temperature.

TABLE 3 Phase evolution in carbonated cement at high temperatures.

\begin{tabular}{lll}
\hline \multicolumn{1}{c}{$\begin{array}{c}\text { Temperature } \\
(\mathrm{OC})\end{array}$} & \multicolumn{1}{c}{ Phase evolution } \\
\hline$\sim 125$ & $\begin{array}{l}\text { Ettringite }\left(\mathrm{C}_{6} \mathrm{AS}_{3} \cdot \mathrm{H}_{\mathrm{n}}\right) \text { seems to form in } \\
\text { the cement due to gypsum }\end{array}$ & 5 \\
$\sim 175$ & gypsum decomposition & 5 \\
540 & decomposition of $\mathrm{Ca}(\mathrm{OH})_{2}$ & 5 \\
825 & $\begin{array}{l}\text { decomposition of } \mathrm{CaCO} \mathrm{CO}_{3} \text { and evolution of } \\
\mathrm{CO}_{2} \text { and formation of } \mathrm{CaO}\end{array}$ & 6 \\
\hline
\end{tabular}




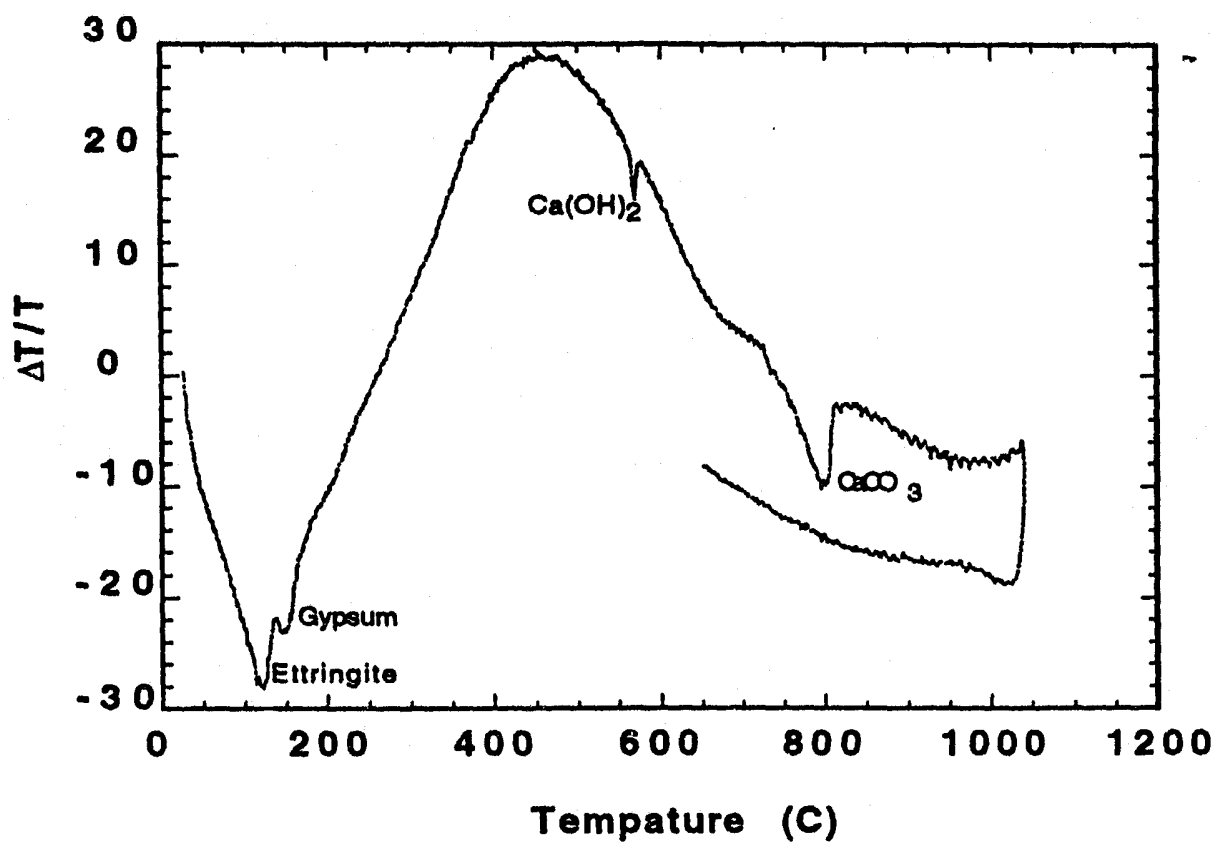

FIGURE 2 Differential thermal analysis of cement cured in $\mathrm{CO}_{2}$.

The analysis suggests that it is possible to estimate the amount of $\mathrm{CO}_{2}$ captured by measureing the weight loss of the cement between $540^{\circ} \mathrm{C}$ and $900{ }^{\circ} \mathrm{C}$. We used this method to estimate $\mathrm{CO}_{2}$ capture in our work. 


\section{iII. STUDIES OF CEMEÑ' PASTE CURED IN $\mathrm{CO}_{2}$ ENVIRONMENT}

To study the effect of the carbonation on setting of cement paste, we investigated carbonation effects on a mixture of Portland cement and silica sand with proportion of the sand varying from 0 to $70 \%$. In this range, samples could be made by pressure-moulding the paste of the mixtures in a cylindrical dye at a pressure of 2000 psi using a press in a uniaxial mode parallel to the cylindrical axis. The pressure was held for $10 \mathrm{~s}$. The ratio of water to the mixture of the powder was 0.125 . During pressing, some water squeezed out of the samples. The samples were made in disk shapes, with a typical thickness of 0.25 " and a diameter of $1 "$.

The curing arrangement contained two identical desiccators, one for air curing and the other for $\mathrm{CO}_{2}$ curing. The desiccator for $\mathrm{CO}_{2}$ curing had an inlet and an outlet for the gas to enter and exit. Both desiccators were air tight and had water at the bottom so that inner atmosphere remained humid. The $\mathrm{CO}_{2}$ was bubbled through water whioch was stored at the bottom of the desiccator, so that the samples were exposed to moist $\mathrm{CO}_{2}$. Samples were placed on wire shelves of both the desiccators just above the water level, so that the specimens had no direct contact with the water. To accelerat the evaporation of this water, an infra-red lamp was kept shining above the transparent covers of both the desiccators. The samples were protectea from the direct radiation by an opaque cover, so that excessive drying of the samples did not occur during curing. 
After curing them for a 30 minute duration in $\mathrm{CO}_{2}$, the samples were dried at $\sim 75^{\circ} \mathrm{C}$. The second set of samples were cured in air also for this duration. However, in this short duration, the samples cured in air did not set. The exact dimensions of $\mathrm{CO}_{2}$ cured samples were measured and then they were tested immediately on an Instron machine in a compressive mode .

The parameter, which describes the relevant mechanical property from practical point of view for the use of cement concrete is the compression strength. This parameter reflects the load bearing ability of cement. The data on the carbonated samples is given in Table 4 .

TABLE 4: Strength and porosiry data on carbonated samples

\begin{tabular}{|c|c|}
\hline Samples & $\begin{array}{l}\text { Compressive strength (psi) } \mathrm{CO}_{2} \text { intake } \\
\text { (\% of sample weight) }\end{array}$ \\
\hline Cement only & 10 \\
\hline $\begin{array}{l}\text { Cement concrete } \\
(50 \% \text { sand) }\end{array}$ & 2612 \\
\hline
\end{tabular}

The data showed that setting and the strength enhancement in carbonated environment is more rapid than in air. Considering that the ASTM requirements for 28 day set Portland cement is 4000 psi, this strength may be obtained in a very short duration of 30 minutes by carbonating the cement paste. Extended studies showed further that During the first day carbonated samples gained a strength more than twice the strength of air cured samples.

To estimate the intake of $\mathrm{CO}_{2}$, the carbonated samples were weighed on an analytical balance and were heated to different temperature 
intervals suggested by the DTA result. The percentage weight losses at each of these temperatures are given in Table 5 .

TABLE 5 Weight loss due to decomposition of various components in the carbonated concrete

\begin{tabular}{lccc}
\hline $\begin{array}{l}\text { Temperature } \\
\text { range }\end{array}$ & $28{ }^{\circ} \mathrm{C}-125{ }^{\circ} \mathrm{C}$ & $125{ }^{\circ} \mathrm{C}-540{ }^{\circ} \mathrm{C}$ & $540{ }^{\circ} \mathrm{C}-9800^{\circ} \mathrm{C}$ \\
$\%$ wt loss & 2.111 & 2.346 & 3.389 \\
\hline
\end{tabular}

The data in Table 5 show that the arnount of $\mathrm{CO}_{2}$ absorbed is $\sim 3.4 \%$. Considering the fact that the samples contain 50\% Portland cement and $50 \%$ sand, this means that $\sim 6.8 \% \mathrm{CO}_{2}$ can be absorbed in cement. It is also interesting to note that at $540{ }^{\circ} \mathrm{C}$, due to decomposition of $\mathrm{Ca}(\mathrm{OH})_{2}$ into $\mathrm{CaO}$ and $\mathrm{H}_{2} \mathrm{O}$, the \% weight loss is $\sim 2.3 \%$. It may be possible to react $\mathrm{CO}_{2}$ with this $\mathrm{Ca}(\mathrm{OH})_{2}$ and produce $\mathrm{CaCO}_{3}$ and sequester more $\mathrm{CO}_{2}$. Such conversions have not been attempted in this project.

To confirm the conversions of dicalcium and tricalcium silicates due to carbonation of the cement according to the Equations 1-4 in the last Section, $\mathrm{X}$ - ray diffraction studies were done. Fig. 4 gives the $\mathrm{X}$ - ray diffraction output before the samples were fired to $980{ }^{\circ} \mathrm{C}$ and after they were fired. The relevant peaks were identified and are labeled in the Figure.

The diffraction output before firing shows clear peaks of $C_{3} S, \beta$ $\mathrm{C}_{2} \mathrm{~S}$, silica and $\mathrm{CaCO}_{3}$. On the other hand, after firing, one can see that the 
peak of $\mathrm{CaCO}_{3}$ has disappeared and now we see peaks of $\mathrm{CaO}$. Neither the peaks of $\mathrm{CaO}$ nor $\mathrm{CaCO}_{3}$ exist in the output of the original cement shown in Fig. 2. The yield of $\mathrm{CaO}$ in Fig. 4 (b) may be due to decomposition of either $\mathrm{CaCO}_{3}$ or $\mathrm{Ca}(\mathrm{OH})_{2}$ or both. However, due to the absence of the peak of $\mathrm{CaCO}_{3}$, one can conclude that the weight loss at $980^{\circ} \mathrm{C}$ is certainly due to evolution of $\mathrm{CO}_{2}$.

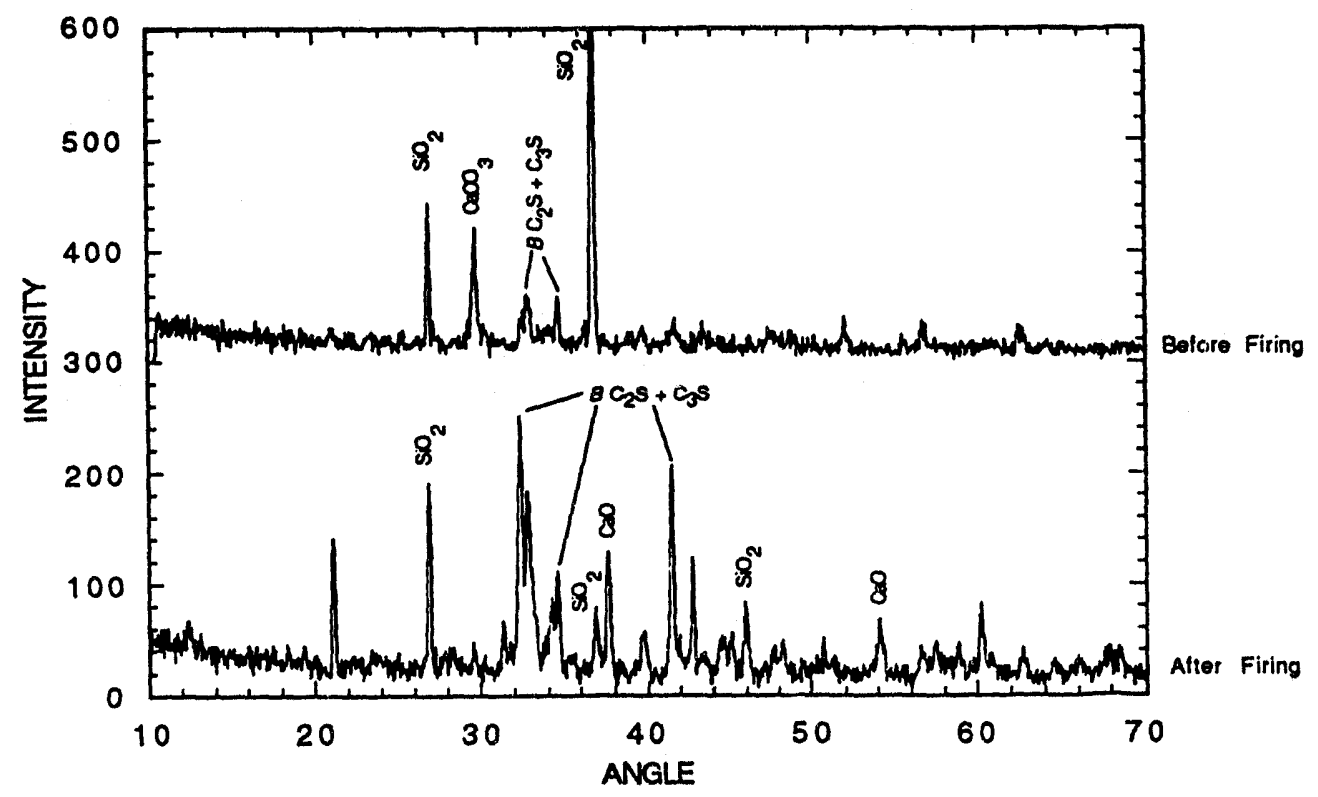

FIGURE 4. X-ray diffraction output of cement cured in $\mathrm{CO}_{2}$. (a) sample as prepared, and (b) sample fired at $8800^{\circ} \mathrm{C}$.

The results presented above imply that the effect of $\mathrm{CO}_{2}$ is significant at the initial stage. Efforts must be concentrated to exploit this feature of curing cements, so that the $\mathrm{CO}_{2}$ can be captured to the maximum extent, 
and simultaneously, curing time can be reduced. Reduction of curing time may provide considerable savings to the industry involved in the prefabricated products of concrete.

One may see two difficulties in effectively achieving this. The permeation of $\mathrm{CO}_{2}$ through thicker structures may be difficult, unless forced circulation is used. Also, often when the samples are wet, the water envelop formed on the particles of the cement prohibits them from reacting with $\mathrm{CO}_{2}$. If these difficulties are overcome, we believe that we will have a useful method to utilize $\mathrm{CO}_{2}$ from flu gas. 


\section{IN SITU CARBONATION 'F PORTLAND CEMENT USING}

AMMONIUM CARBONATE AS A VEHICLE OF $\mathrm{CO}_{2}$

\section{III.1 Ammonium carbonate as a vehicle of $\mathrm{CO}_{2}$}

Ammonium carbonate is a crystalline chemical, which is unstable and decomposes easily at even a slightly elevated temperatures. It is soluble in water and for hydration setting of cement, it may be used as a vehicle of carbon dioxide. With the exothermic reaction of the setting of cement, ( $\left.\mathrm{NH}_{4}\right)_{2} \mathrm{CO}_{3}$ decomposes into $\mathrm{CO}_{2}$ and $\mathrm{NH}_{3}$ and provides the necessary $\mathrm{CO}_{2}$ to the setting cement. The amount of water to be added to the cement powder is governed by the workability of the paste. Too much of water makes the paste too dilute and it does not set into required shapes. Also excess water makes the samples porous. In Type I Portland cement, we found that the workable ratio of cement to water is $5: 1$, even though this ratio automatically puts a limit on the amount of $\mathrm{CO}_{2}$ which can be made available to the setting cement.

For saturated solution of $\left(\mathrm{NH}_{4}\right)_{2} \mathrm{CO}_{3}$ equal amount of this material and water were mixed. To form a supersaturated solution, we put in $28 \mathrm{~g}$ of $\left(\mathrm{NH}_{4}\right)_{2} \mathrm{CO}_{3}$ crystals to $20 \mathrm{~g}$ of water, and $100 \mathrm{~g}$ of the cement powder was stirred into this solution. When the slurry becomes warm, it was poured into cylindrical moulds of radii $2.55 . \mathrm{cms}$ and heights ranging from 1.5 to 2.cms, and samples were moulded at a pressure of 2,000 psi. Mixing and moulding lasted for $\sim 15 \mathrm{~m}$. During this time ammonia was being released from the samples indicating decomposition of the carbonates into $\mathrm{CO}_{2}$ and $\mathrm{NH}_{3}$. The samples were immediately transferred into a desiccator containing saturated solution of $\left(\mathrm{NH}_{4}\right)_{2} \mathrm{CO}_{3}$ for further curing. 
To make the concrete samples, cement powder was mixed with silica sand in the desired ratios. The ratio of the concrete : water : $\left(\mathrm{NH}_{4}\right)_{2} \mathrm{CO}_{3}$ was maintained at $100: 20: 28$. Samples made this way were subjected to the various tests given below.

\section{III.2. Identification of minimum time of setting}

During setting, it is expected that due to the exothermic reaction, the temperature of the solution will increase. A thermometer was used to monitor this temperature during setting. Fig. 5 shows the temperature build up in the paste during first few minutes of setting. After a slow rise of the temperature for first 12 minutes, the temperature was $52^{\circ} \mathrm{C}$ within next three minutes. It subsequently dropped equally fast and was $22{ }^{\circ} \mathrm{C}$ in next $5 \mathrm{~m}$. We believe that initial rise in temperature releases $\mathrm{CO}_{2}$ from the solution. Capture of this $\mathrm{CO}_{2}$ sets the cement faster, which raises the temperature further. The process continues till all $\left(\mathrm{NH}_{4}\right)_{2} \mathrm{CO}_{3}$ decomposes and most of the $\mathrm{CO}_{2}$ is captured in first $15 \mathrm{~m}$. After this period, the cement returns to its normal setting rate and the temperature falls due to dissipation of the heat energy. This implies that most of the setting of the cement occurs in first $15 \mathrm{~m}$. Thus further curing does not increase the setting rate considerably. This was confirmed by direct measurements as follows.

III.2. Estimation of $\mathrm{CO}_{2}$ captured:

Samples of cement were fabricated and cured in the desiccator with the solution of $\left(\mathrm{NH}_{4}\right)_{2} \mathrm{CO}_{3}$ for different time periods. At the end of each period, samples were dried and then were heated to $950^{\circ} \mathrm{C}$ to drive away 


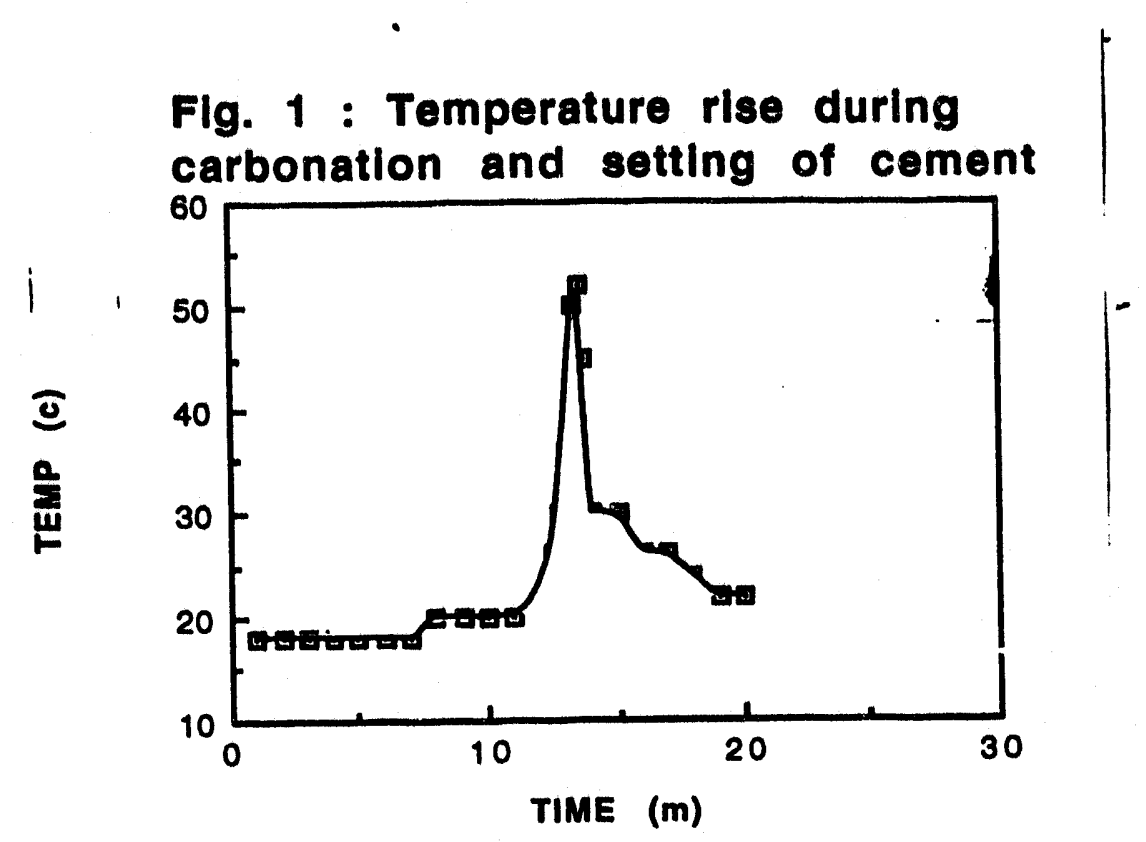

FIGURE. 5 : Temperature rise during carbonation and setting of cement

Fig. 2 : Time dependence of carbonation

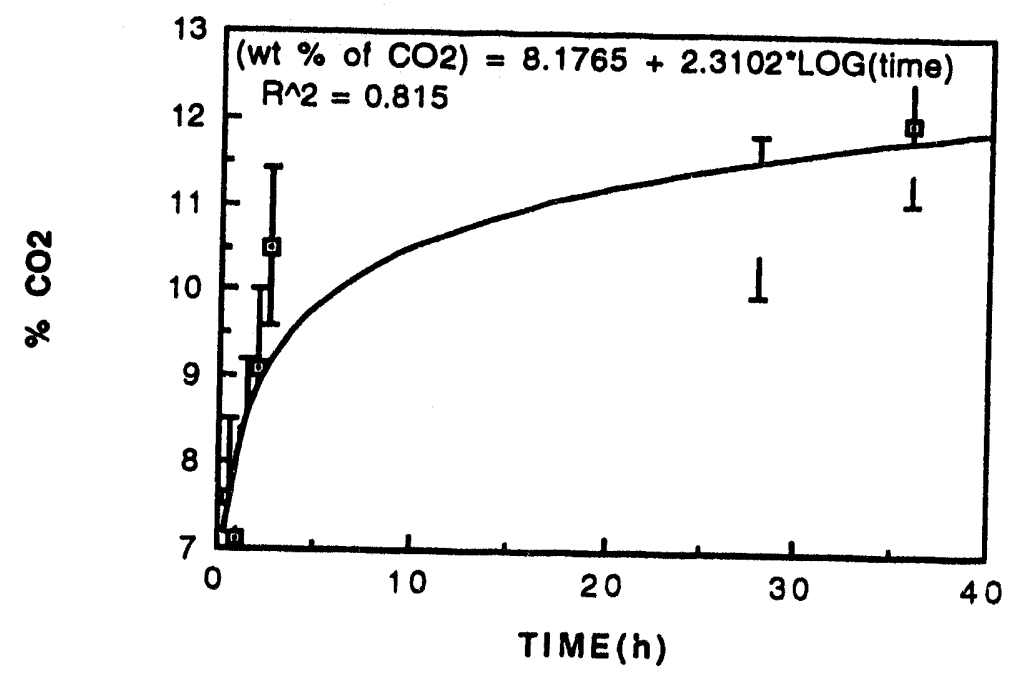

FIGURE. 6.

Time dependence of carbonation 
all $\mathrm{CO}_{2}$ from the samples. This allowed us to estimate the amount of $\mathrm{CO}_{2}$ captured in the specimens by the procedure described in Section II. The results are given in Fig. 6 .

Each data point in Fig. 6 is an average of readings on four samples. The time needed to press these samples and to place them in the desiccator varied between $5 \mathrm{~m}$ to $10 \mathrm{~m}$, with an approximate average of 7 m. Thus the curing time on each sample was this initial time plus the time shown on the $\mathrm{x}$-axis.

The amount of $\mathrm{CO}_{2}$ captured appears to be a logarithmic function of time. Initially, the capture occurs at a fast rate, but subsides in approximately $15 \mathrm{~m}$ of total curing. This is consistent with our earlier interpretation of the data in Fig. 4. Initially, $\mathrm{CO}_{2}$ is captured from the solution that was added to the cement during setting. However, the solution in the desiccator is at the room temperature and the sample has cooled down during transfer to the desiccator. In such environment, the rate of carbonation is low and hence the curve in Fig. 5 tapers off. This implies that one could consider about $15 \mathrm{~m}$ curing time for most of the carbonation to occur. We decided to cure the samples for $30 \mathrm{~m}$ for practical reasons in our future study.

\section{III.3 Carbonation in concretes:}

Cement is mostly used as the binding phase in concrete. Therefore it is necessary to study carbonation of concrete. For this reason, we prepared samples of concrete by mixing cement and silica sand in various 
proportions and carbonated them according the procedure given above. In each case the amount of $\mathrm{CO}_{2}$ captured was estimated. The results are given in Fig. 7.

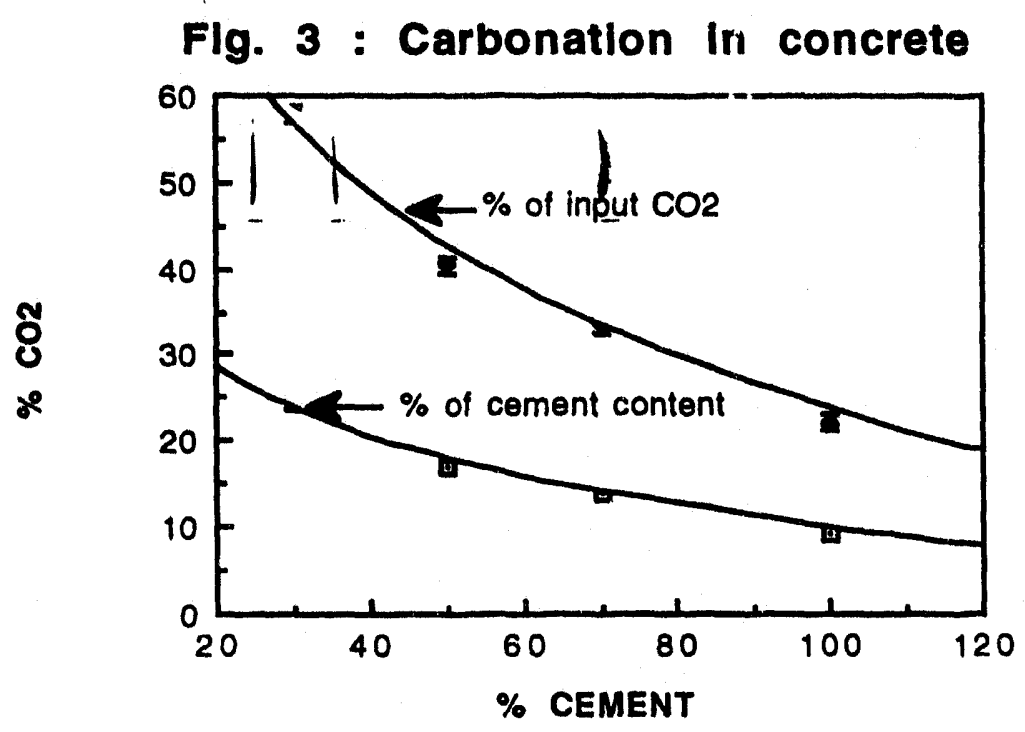

FIGURE. 7 : . $\quad \mathrm{CO} 2$ capture as a function of wt $\%$ of cement in concrete

The results show that the dependence of the amount of $\mathrm{CO}_{2}$ captured is again a function of the cement content. The fact that it is not a linear function indicates that there are other factors influencing the carbonation. We believe that the porosity might be affecting the carbonation of the concrete. At small content of the cement in concrete, the porosity is expected to be higher. This will result in an exposure of more surface area of the cement component to the $\mathrm{CO}_{2}$. This will result in higher $\mathrm{CO}_{2}$ capture at lower concentration of the cement component.

At $30 \%$ of the cement content, $24 \% \mathrm{CO}_{2}$ is captured. It is $56 \%$ of the $\mathrm{CO}_{2}$ produced during calcining of $\mathrm{CaCO}_{3}$ for producing that cement. At 
higher content of the cement in the concrite, this percentage is reduced to $\sim 9 \%$ at $100 \%$ of the cement. This variation is also shown in Fig. 6

IV.4. Microstructure of the carbonated cement

Fig. 8 presents the scanning electron micrographs of the fractured surfaces of the uncarbonated and carbonated cement. As one may see, the structures in the two cases are different. In the case of uncarbonated samples, except for very fine needle like structures, the major phase is noncrystalline. The fine needles are likely to be those of ettringite. On the other hand, the micrograph of the carbonated sample shows prizmatic structures of arogonite $\left(\mathrm{CaCO}_{3}\right)$ formed out of the $\beta$-dicalcium silicate and tricalcium silicates after carbonation. These observations are consistent with those made by Young et al. [3] on synthesized dicalcium and tricalcium silicates. In addition to these, one may also notice that the crystals are coated by a layer of spheroidal structure. Such spherical structures are found every where in the material. Typical size of these structures is less than a micron. We have not identified these structures as yet. They do not appear in the carbonated dicalcium and tricalcium silicates studied by Young et al., which implies, they might have been formed out of alumina or sulfur present in the Portland cement.

IV.J. Effect of carbonation on reinforcement of steel

Finally we addressed the issue of effect of carbonation of cement on the reinforcement of steel. It has been reported [1] that one of the problem of carbonation of cement is the deterioration of the bond 

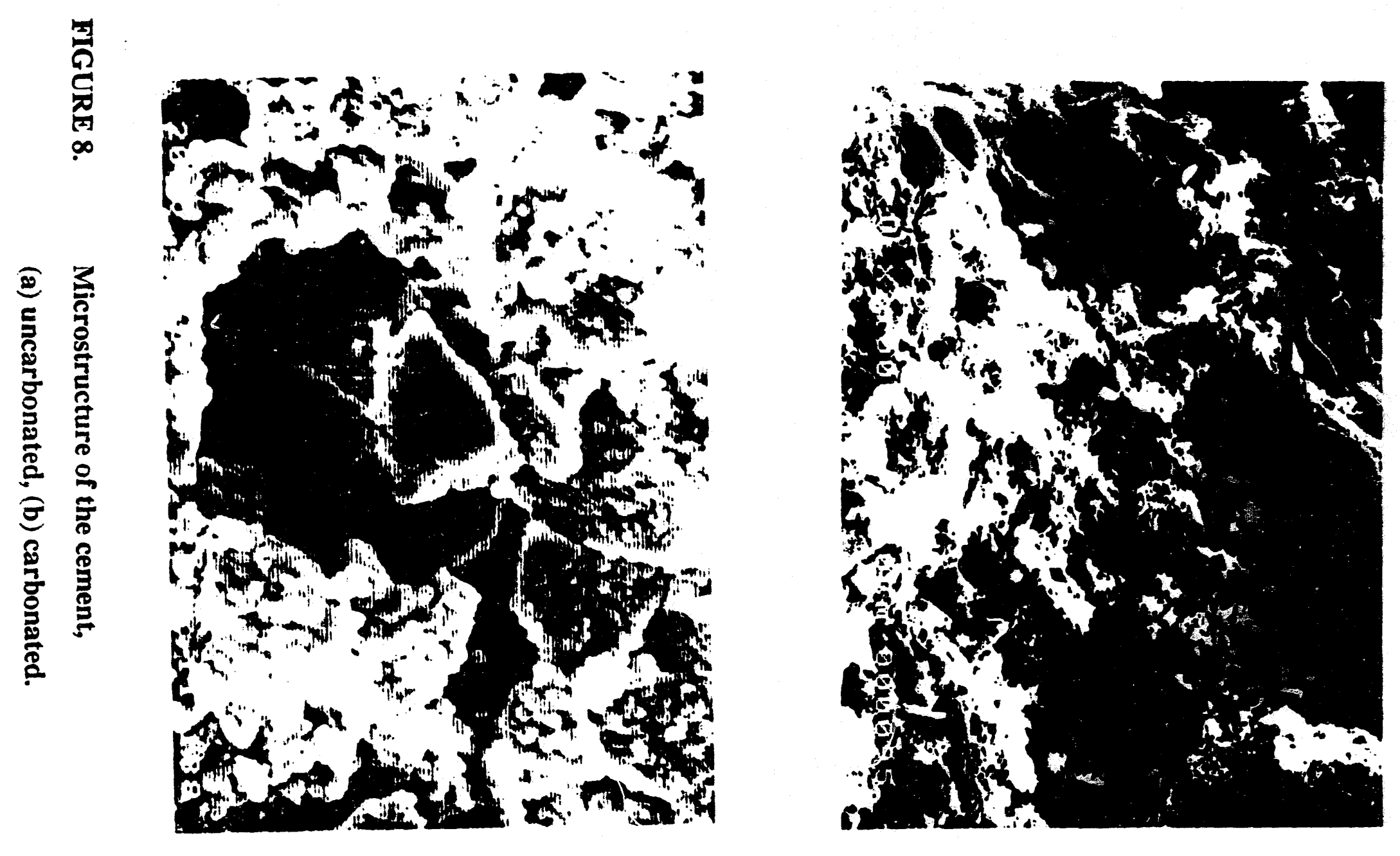
between the cement matrix and the reinforcement steel. Carbonation reduces the $\mathrm{pH}$ of the setting cement. Lower $\mathrm{pH}$ is detrimental to the development of the protective corrosion layer on the surface of the steel, which in turn does not allow good bonds between the steel and the cement matrix. We confirmed this by incorporating low carbon steel wires in the cement matrix and carbonating the samples externally by putting them in a carbonation chamber. The bonding was found to be poor. On the other hand, when the wires were put in the the paste which was prepared with ammonium carbonate solution, and set, the wires were bonded well in the cement matrix and could not be separated. When the sasmples were fractured with an impact force, the matrix cracked, but the wires bonded in the matrix.

The reason for this bonding is clear. During carbonation, ammonia is released, which maintained high $\mathrm{pH}$ of the paste. Direct measurement showed a pH of 12 , which is nearly the same or slightly higher than that of setting cement in water. Thus use of ammonium carbonate as a vehicle helps to maintain the pH high during setting, which in turn helps good bonding between the reinforcement of steel to the matrix. 


\section{DISCUSSIONS AND RECOMMENDATIONS}

The investigations reported here show that carbonation of Portland cement can reduce the setting time of the cement considerably. In particular, using ammonium carbonate, one can capture significant amount of $\mathrm{CO}_{2}$ in cement, which can reduce the $\mathrm{CO}_{2}$ emissions in cement industry. The setting time is less than half an hour, which can save considerable time and money to an industry involved in the production of precast components of cement. Use of ammonium carbonate also provides a compatible process to reinforce cement structures with conventional reinforcement steel.

\section{V.1 Recycling of ammonia during carbonation}

The evolution of ammonia may be of some environmental concern during carbonation of the cement. However, ammonum sarbo.sate may be formed by resynthesis of the evolved ammonia with green-house carbon dioxide. Preliminary studies on such resynthesis show that this is possible. Thus, it may be recycled in the process, which not only avoids its evolution in the open atmosphere, but also makes the entire process economical. This is shown in the schematics in Fig. 9.

The work done in this project shows the feasibility of sequestering green-house carbon dioxide at the bench scale. It is highly recommended that a working model be attempted to demonstrate the feasibility of the scheatic model shown in Fig. 6 and develop a pilot scale production facility to assess the economic feasibility. 


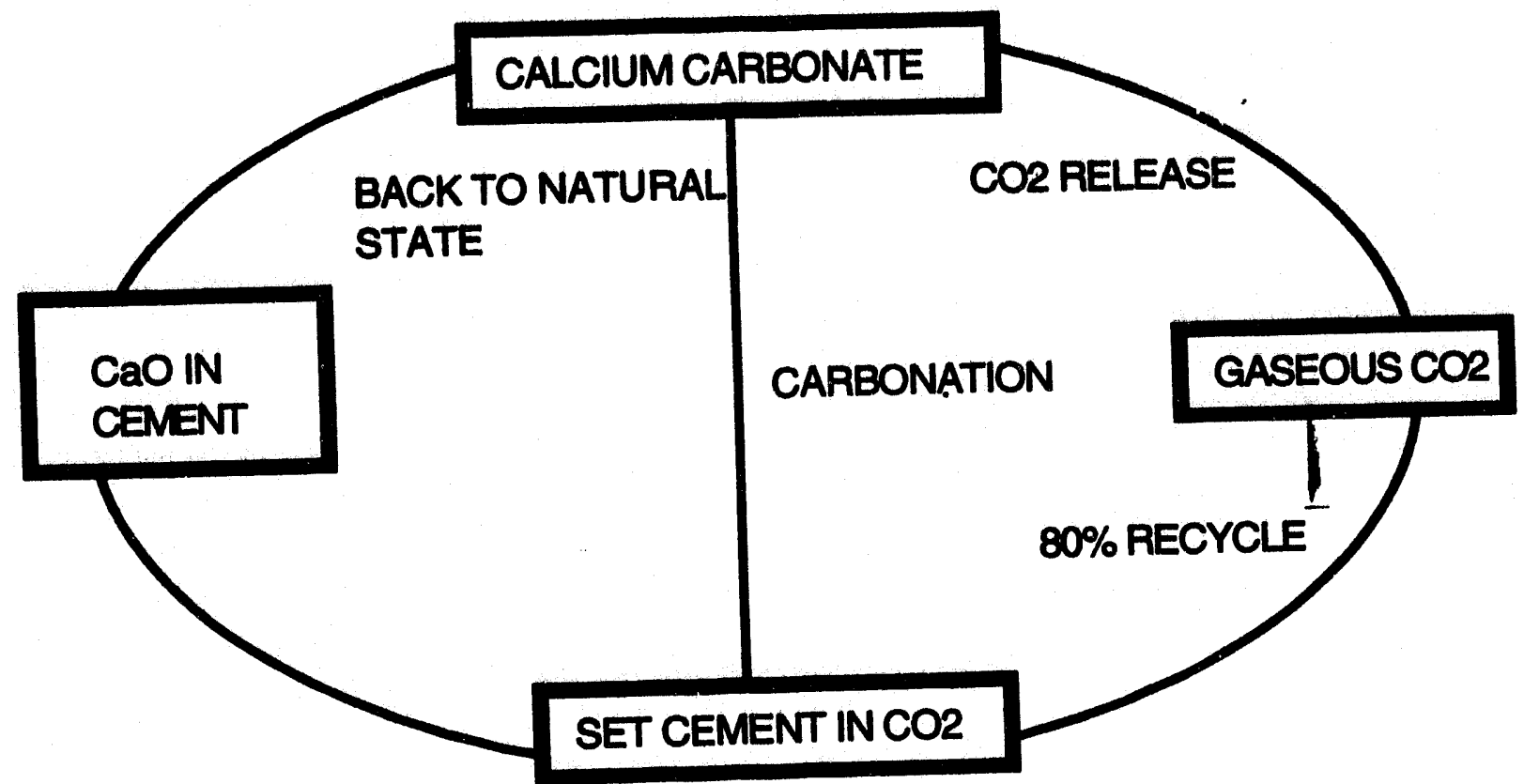

FIGURE. 9

Proposed $\mathrm{CO} 2$ cycle in the cement industry.

\section{V.2 Coclusions and future directions}

No process, designed to reduce environmental pollution, becomes commercially viable, unless it is also economical. The work conducted in this project developed a process to sequester green-house carbon dioxide in Portland cement, which not only reduces the green house gases produced by the cement industry, but also reduces the cost of the production of construction products. Therefore it should be a commercially viable process.

The process needs some fine tuning. It is necessary to understand the details of the microstructure of the carbonated cement, sto gain complete confidence in the carbonated cement and also to optimize the 
process and the properties of the cement. It is also necessary to develop a working model of the cyclic process shown in Fig. IV.1. Such a model will attract industrial interest. That will help development of collaborative projects with the cement industry and the technology transfer for the overall economy of the industry and for a better environment.

References:

1. Davidovits, J., ' $\mathrm{CO}_{2}$-Greenhoüse Warming! What future for Prtland Cement?' in Proc. Emerging Technologies Symp. on Cement and Concretes in the Global Environment, March 10-11,1993. Pub. Portland Cement Association, Skokie, Il.

2. R. L. Berger, J. F. Young, and K. Leung, "Acceleration of Hydration of Calcium Silicates by Carbon Dioxide Treatment" Nature (London) Phys. Sci. 240 [97] 16 - 18 (1972).

3. J. F. Young, R. L. Berger, and J. Breese, "Accelerated Curing of Compacted calcium Silicate Mortars on Exposure to $\mathrm{CO}_{2}$, J. Am. Ceram. Soc. 57 [9] 394 - 397 (1974).

4. C. J. Goodbrake, J. F. Young and R. L. Berger, "Reaction of Hydraulic Calcium Silicates with Carbon Dioxide and water, J. Am Ceram. Soc., $62[9-10] 488-491$ (1979). 
5. Portland Cements, Reprinted from Design and Control of Concrete Mixtures (EB001.13T), Chapter 2. Published as Concrete Information, by Portland Cement Ass. (1988).

6. T. Nishikawa, K. Suzuki, S. Ito, S. Sato and T. Takabe, "Decomposition of synthesized ettringite by carbonation, Cement and Concrete Research, 22, 6-14 (1992).

5. X. Zhao, B. E. Scheetz, and M. R. Silsbee, "The hydration of fluidized bed combustor ashes", Presented at Am. Ceram. Soc. 95th Annual Meeting, Cincinnati, OH, April 19 (1993), Abstract no.SVIII -7-93.

7. Materials Safety data Sheets for $\mathrm{CaCO}_{3}$, johnson and Matthey, 30 Bond St., Ward Hill, MA 01835. 

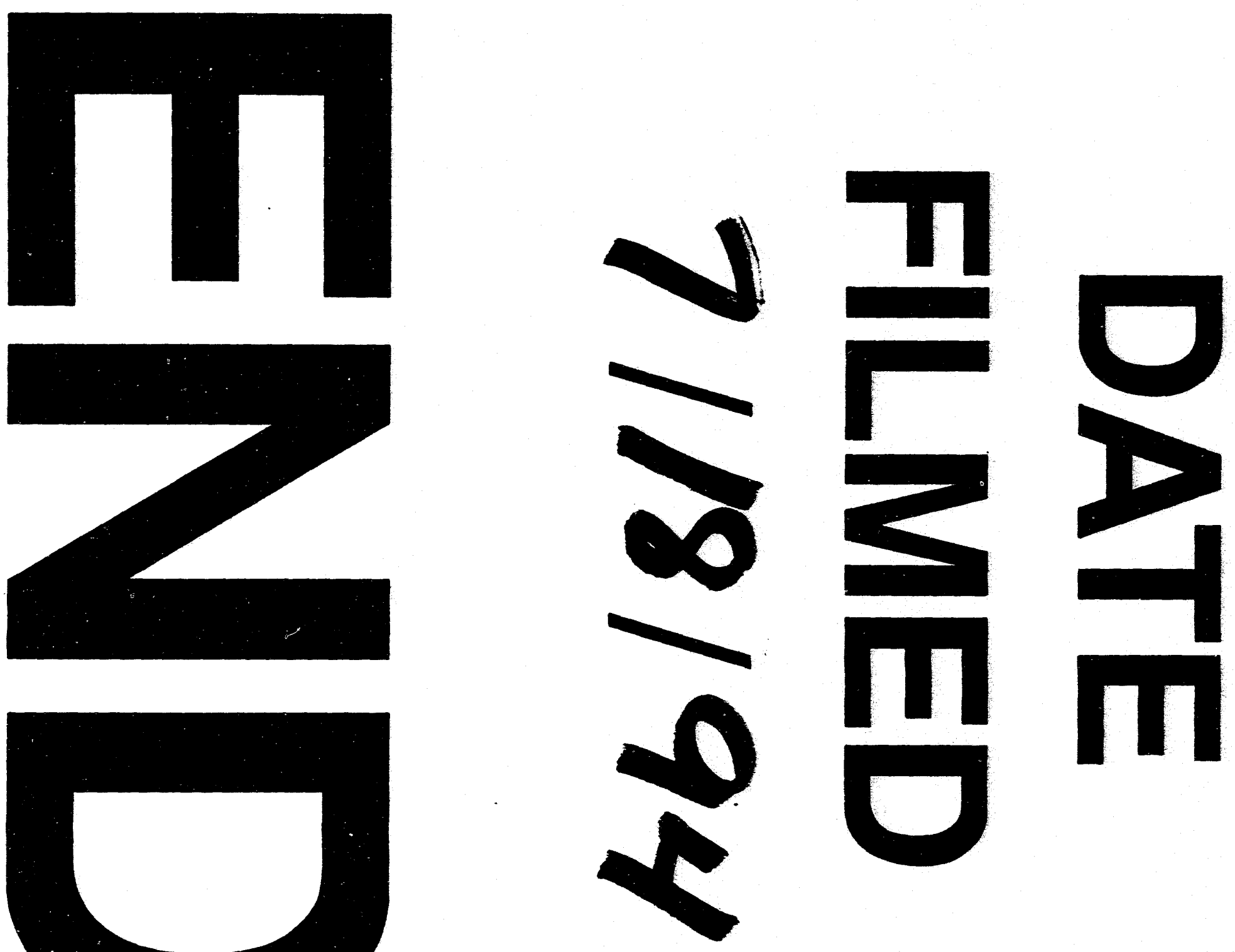

目

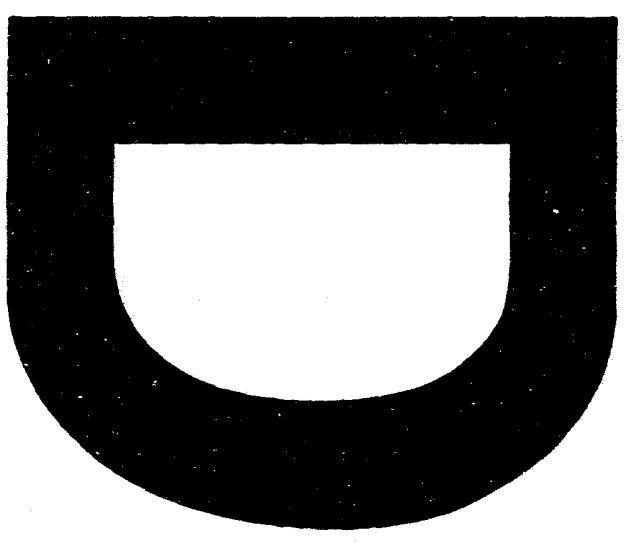




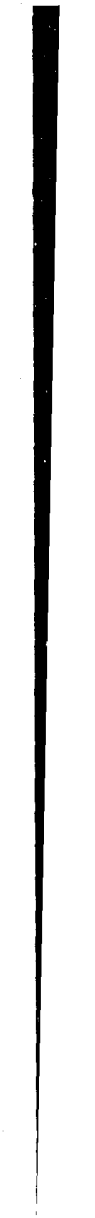

